\title{
Marta Dvořák, Mavis Gallant: The Eye and the Ear
}

\section{Danielle Schaub}

\section{(2penEdition}

\section{Journals}

Electronic version

URL: http://journals.openedition.org/ces/4363

DOI: $10.4000 /$ ces.4363

ISSN: 2534-6695

\section{Publisher}

SEPC (Société d'études des pays du Commonwealth)

\section{Electronic reference}

Danielle Schaub, « Marta Dvořák, Mavis Gallant: The Eye and the Ear », Commonwealth Essays and Studies [Online], 43.1 | 2020, Online since 30 October 2020, connection on 09 November 2020. URL http://journals.openedition.org/ces/4363 ; DOI : https://doi.org/10.4000/ces.4363

This text was automatically generated on 9 November 2020

\section{(c) $($ i) $(9)$}

Commonwealth Essays and Studies is licensed under a Licence Creative Commons Attribution - Pas d'Utilisation Commerciale - Pas de Modification 4.0 International. 


\title{
Marta Dvořák, Mavis Gallant: The Eye and the Ear
}

\author{
Danielle Schaub
}

\section{REFERENCES}

Marta Dvořák. Mavis Gallant: The Eye and the Ear. Toronto: Toronto University Press, 2019. 261 p. ISBN: 9781487505301 (hb). \$65

1 Mavis Gallant has puzzled numerous readers, owing to the multidimensional allusiveness and polyphonic quality of her works coupled with indirection, disjunctiveness, irony and shrewd vision. Marta Dvořák's Mavis Gallant: The Eye and the Ear sets out to remedy their bafflement by unfolding the multiple layers of the author's work, applying her profound knowledge of stylistics and poetics as well as making the most of her intimate relationship to the writer, rich in informal conversations and more focused correspondence. Surveying the culture Gallant imbibed at various stages of her life, Dvořák throws light on what shaped the writer. Expanding on aspects addressed before by others and broaching on novel aspects, she superbly discusses Gallant's overall craft and her writing's infusion with techniques informed by her lifelong and wide-ranging acquaintance with the cinematographic, literary, musical and painterly worlds.

2 Dvořák starts out with an acrostic for Gallant to capture the essence of the author's world and work and to foreground her own argument astutely with its artistic, literary and philosophical incursions. Regarding ekphrastic and literary references, Dvořák points to their subtle, and often ironic, dynamics in Gallant, encompassing the spirit of the time. Reflecting on the osmotic connection between literature and the visual arts, she then considers the interaction between the visual and the auditory in cinema, ballet and opera. The clarification of the interactiveness between the verbal, the visual and the auditory aptly prepares for close-readings emphasising linguistic and rhythmic 
patterns that alternate with philosophical and artistic considerations as well as insights garnered from personal revelations.

Through microanalysis of extracts from varied stories, Dvořák at first throws clear light on Gallant's glowing, lively, precise use of words, dense and tight prose combining compression and expansion through metaphors, enumeration, polyphony, sound and rhythm. She then turns to Gallant's mastery of rhetoric devoid of banality in spite of her not adhering to earlier modernists' use of eccentric turns. She attributes such mastery to the oral quality of Gallant's sentence structures and their alternation of increasing and decreasing complexity, parallelism and antithesis, chiasmus, coupled contraries - the source of her irony. Her subsequent discussion of meter, patterns reminiscent of film techniques and Cubist juxtaposition leads to novel understanding of Gallant's craftsmanship as does her focus on dissonance and syncopation to avoid predictability, calling upon cinematographic, musical and literary characteristics.

In her chapter on "Text/Image Borderblur \& Cubist Realism," Dvořák skillfully grasps Gallant's use of mixed perspectives - with examples from some of the most complex stories - comparing it to Picasso's Cubist painting, or to Hockney's photo-composites or collages. The analogies drawn between the visual and literary texts - Gallant's or other master writers' - point to the stunning width of Dvořák's knowledge in different fields, from which her brilliant textual analyses of Gallant benefit. Her final comments on the author's genre-crossing in her stories - between fiction and essay, "between portrait and self-portrait" - explain "the absence of plot" so characteristic of numerous Gallantian stories.

Carrying over the Cubist multiplicity of vantage points, Dvořák then concentrates on the disruptive presentation of time and space as well as on the changing voices and focal points so prevalent in Gallant's writing. Ample analogies with visual artists, on the one hand, and Modernist and Romantic authors, on the other, serve to elucidate her talent at disjunctive simultaneity. Text explication of various passages from stories showcases the abundant ways in which Gallant introduces ruptures that dislocate and relocate at once, that signal diverse moments in time and different stages of perceptual consciousness particularly in first-person narrations. Dvořák then reflects on the riddles afforded by the shifting deictics that collide different enunciators, places and times, leading to the chapter's title - "Who Is I \& When Is Here?" Such distortions create slips from the personal to the plural or the universal, or from subjective to objective perspective, or even "fluctuating [...] subjectivity" (183). Likewise, the examination of Gallantian similes, metaphors, and other figures of speech points to conjoining, compressing, crisscrossing views, ending in either doubling "short cut" or estranging "short circuit." Continuing her analogy with the artistic, literary and musical frame, Dvořák rounds off her critique by inscribing her vision of Gallant's oeuvre as engaged in forever drawing together contrary outward, or disjunctive, forces with inward, or unifying ones, transformation and stability in perpetual readjustment.

Dvořák adopts subsections throughout her chapters, demonstrating thereby the impossibility of giving a clear comprehensive view when it comes to the work of an author so accomplished at cumulating contrasting techniques, at engendering polyphonic perspectives and at breaking patterns; the variety of digressive prowess alone accounts for the need to subdivide the argument. With the numerous comparisons to other fields, Dvořák's book may prove difficult for readers untrained in the critical terminology, but will no doubt delight trained readers. I therefore gladly 
second W.H. New's succinct but powerful back-cover appreciation of her study as "a major accomplishment, nothing short of a new poetics of style," indeed the true achievement of maturity. However, given Dvořák's unquestionable expertise and scholarship, she surprisingly does not account for the genealogy of some ideas she develops. She disregards Janice Kulyk Keefer's insightful Reading Mavis Gallant (1989) and its emphasis on style, irony and humour bordering on satire, narrative voice and structure together with some thematic chapters on children, women and history. Neither does she refer to the Twayne's World Authors' book on Gallant (1998) explicating texts through extensive close-reading with similar, though perhaps less overarching, findings, in chapters on multi-voiced narration, distance and disharmony, irony, space, text and image, style and painting. She also overlooks a few articles, amongst others those on the pictorial in Mavis Gallant published in a book including an article of her own, namely Image et récit: littérature et arts visuels du Canada (1993). Though such oversight raises questions as to basic acknowledgement of indebtedness to previous research paving the way for hers, it does not detract from Dvořák's excellent argument and wide-ranging exploration of Gallant's work grounded in overwhelming multifaceted artistic, literary and philosophical parallels.

\section{AUTHORS}

\section{DANIELLE SCHAUB}

Oranim College of Education, Israel

Danielle Schaub has published numerous articles on Canadian literature, especially on Canadian and Québécois women writers. She has published and coedited books on Canadian authors, and (co)edited several collections of essays on cultural space, ethnicity and identities, community and nation, mixed heritage in Canadian literature. Her creative works include a prized collection of photographs and texts entitled Reading Writers Reading: Canadian Authors' Reflections (University of Alberta Press, 2006) and Interior Views: Photopoetry (Rubicon Press, 2009). Her training as a bibliotherapist has led to both articles and three coedited collections on trauma, the current focus of her research on Canadian literature. 